\title{
Al-Qaeda, ISIS, Boko Haram and Forms of Rebellion in the 21st Century in the Vacuum of Ottoman and Soviet "Collapse"
}

Niccolo Caldararo*

Department of Anthropology, San Francisco State University, USA

"Corresponding author: Niccolo Caldararo, Professor, Department of Anthropology, San Francisco State University, USA, Tel: 415-453-9064; E-mail: cald@sfsu.edu

Rec date: Feb 09, 2016; Acc date: Feb 18, 2016; Pub date: Feb 25, 2016

Copyright: @ 2016 Caldararo N. This is an open-access article distributed under the terms of the Creative Commons Attribution License, which permits unrestricted use, distribution, and reproduction in any medium, provided the original author and source are credited.

\begin{abstract}
With the collapse of the alternative ideologies of the 20th century, capitalism has had several decades of unopposed influence across the globe. This has had an increasing result of changing the lives of people in the mould of the west to the dismay of many peoples. No ideology unites them, no international organization can protect them from armies and corporate militias and death squads. National governments call those who resist "terrorists" and so class any actions of self-defense. We have entered an era of global conflict between traditional peoples and corporations where one way of life is being exterminated. While it is in general a continuation of the assault of western colonialism, today's indigenous rebels instead of being considered devil worshipers are now often seen as minions of terror. Political rebellions, armed gangs and drug lords and religious terrorism appear to form a range of types with conquest of territory the goal on one end and operational integrity (e.g., business) at the other as in oligarchs morphing into warlords and presidents (as in Chechnya and Ukraine). At the same time international confrontations and competition for resources are escalating. The defeat of the USSR is often described as a "collapse" of authority and transition to a new civil entity, Russia, but like the defeat of the Ottoman Empire, it has resulted in a dismemberment of the Soviet Empire. Where the Middle East remains unstable 100 years after the Ottoman defeat, the Russian periphery has become unstable in both independence movements along its southern borders as well as those flanking Europe. The demise of both empires threatens the stability of the world today.
\end{abstract}

Keywords: ISIS; Al-Qaeda (Al-Qa'ida); Boko haram; Terrorism; Repression; Iraq; Afghanistan; Yemen

\section{Introduction}

Today we find a rising threat to the daily life of people from terrorism and anti-terror activities by governments. Yet the only organized resistance to global development exercised by transnational corporations, drug gangs and death squads and the nations from which their power has risen, is increasingly seen by the poor and dispossessed of the world as al Qaeda or similar entities. Similar local off shoots like ISIS/IS have also appeared, though remnants of Maoist movements persist in some areas as in India with the Naxalites [1,2]. Other guerrilla groups are remnants of states failed in the Cold War struggle as in the case of Somalia and Yemen. Yet around the world, from the uprisings in India by traditional peoples against the Vedanta mining \& development schemes Anon [3], in Panama the Ngobe-Bugle Indian tribe, to the recent massacre in the Amazonas Province of Peru, native people are striving to protect their lands from resource extraction and environmental pollution [4]. We have entered an era of global conflict between traditional peoples and corporations where one way of life is being exterminated. While it is in general a continuation of the assault of western colonialism, today's indigenous rebels, instead of being considered devil worshipers as they were in the past, they are now often seen as minions of terror. The roots of contemporary terror are not just seen in the disorder created by colonialism, but in the very form it has taken. Saudi Wahhabism was brought to power by the British in their support of Abd al-Aziz or Ibn Saud with arms and advice before the First World War to undermine Ottoman attempts to suppress the violent fanaticism of Abd al-Wahhab and Muhammad Ibn Sa'ud that followed their uprisings after $1746[5,6]$. What is contradictory is that while the west concentrates on militant groups in various Islamic countries that are fighting for Sharia law and an Islamic state, this is what Saudi Arabia has now and has promoted abroad through its donations, foreign aid and educational foundation activity. But as Doran [7] notes the Saudi government has a long history of promoting conservative Islam, trying to balance its role in a secular and Christian dominated world and yet attempt to limit the role of Shia Islam.

The consequences of this support have stemmed from the creation of the totalitarian state of the Saudis and the spread of fanatic Wahhabism by the use of oil money. In the past two decades increasing international confrontations and competition for resources have escalated. Current assaults on national territories from Yemen to Columbia in search of a pacification of activities that are seen as "terrorist" and inconsistent with global capitalism often reflect a process of repression of local political resistance to development. Actors are frequently left little recourse to peacefully resist after corrupt legal processes deny their standing to block development. These pressures are bound together as in the case of Saudi based Wahhabi proselytizing and regional (e.g. Egyptian bombardment of Sa'da) and international intervention (Soviet and American client support) [8]. Yemen was divided into north and south portions between the British (south) and Ottoman (north) at the beginning of the 20th century. Main resistance to outside control, whether Ottoman in the 16th and 17th centuries or British has been from the Zaydi. Yet Zaydi influence has been contested by Sunni Wahhabi from Saudi Arabia and that conflict has continued to the present [9]. The present Houthi rising can be seen as a continuation of this conflict. And the Saudis have not escaped the consequences of this export fanaticism, as Hegghammer [10] notes, the rise of the Sahwa movement in the early 
1990s, especially after the arrival of US troops in the Gulf Wars led to rising tensions and violent confrontations.

The negative effects of culture change attendant to colonialism have long been recognized. Bodley [11] has published an effective crosssection of these effects of interventions. Education has been one element in this process, partly positive in producing a trained native cadre for post-colonial adaptation, but in many cases, as Goody [12] has shown from West Africa, individuals become educated but can find no jobs, yet do not wish to return home to farm work and often fail to produce the traditional help and aid for parents and family. In this context the response of Boko Haram can be seen, not as a mindless rejection of Western knowledge and training in technical skills, but in frustration in the economic and social consequences of such training.

The appearance of ISIL/IS/ISIS parallels the evolution of some other rebel groups in the past five decades where social issues are transformed by repression into armed struggle and then support for military infrastructure and material requires economic activities like kidnapping, drug trade, bank robbery, smuggling, especially in resource extraction (logging, oil, minerals, etc.) and shadow banking. A recent report on ISIS's oil trading argues that it has taken over preexisting networks of oil smuggling in Iraq and Syria, but ISIS's political and economic sophistication appears to outstrip conventional rebel and criminal gang complexity [13]. Usually the evolution of criminal gangs from illegal activities, as in alcohol in the USA in the 1920s and 1930s to legitimate investments took new forms in the post WWII period where drug lords, because of the long existence of the drug war and increased demand, began to control extended territories of land and business across countries like Columbia [14-16]. ISIL/IS's complexity belies a longer history, one that may be part of state sponsored regional wars as in the Contras in Central America or Unite in Angola [17] (Figure 1).

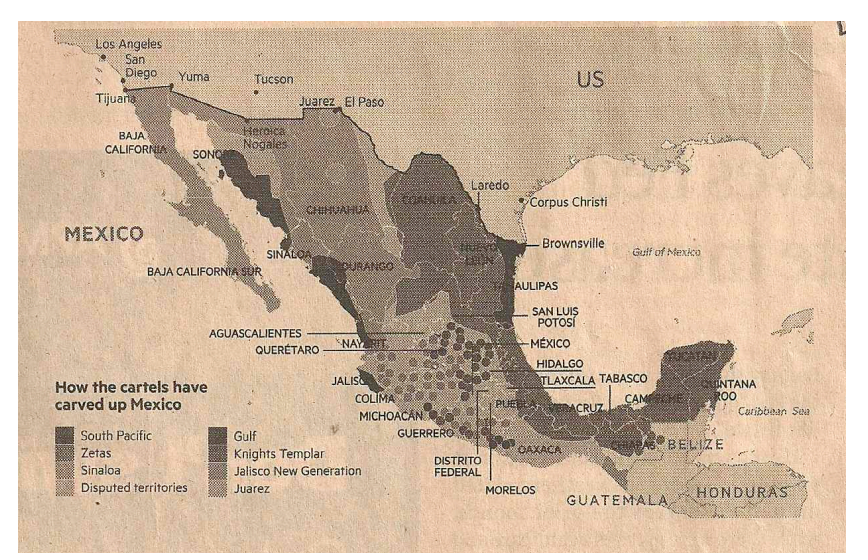

Figure 1: Fragmentation of Mexico by drug lords from the financial times $5 / 8 / 15$.

What is new is the overwhelming uniformity of opposition to local control and democracy by corporate power. Resistance has taken the form in the world press as the combination of drug war, religious terror and new media. But what seems also to be ignored is that everywhere in the world where there is change driven by global economics there is unrest and this unrest is a problem for the West as it is for China and other "BRICS" and yet it is an opportunity for religious militants like al Qaeda for it could form the basis for a new ideological challenge to Christian Capitalism, as well as State Capitalism (whether ideological as in China, or opportunist as in Russia) "Third" forms of capitalism as in Japan and Social Democratic capitalism (NGO philanthropy supported by large sovereign funds as that of Norway). All these forms are linked in an ideology of progress and development. Intertwined with this fragmentation of formal states has been their reduced power and the growing power of global cities, their connectivity and corporate agreements [18].This "everywhere" is not just the hinterlands, but the massive "underdeveloped" slums and shantytowns that surround the cities of the 21st century [19]. The organization of forms of rebellion can be placed into a range of type based on origins, support and ends (Chart 1).

Organization of Forms of Rebellion in the 21st Century

Drug gangs War Lords Death Squads Ideological Rebels Religious

Entrepreneurial ${ }^{* \star * * * * *}$ Cold War or Colonial, State ${ }^{\star \star * * *}$ indigenous

Social unrest ?rebellion?Warlords?Drug war?Terrorism

Social unrest?rebellion Seizure of Power? Protracted Civil War

Chart 1: Organization of forms of rebellion in the 21 st century.

While the combination of terror and drugs is not new, having become a relatively successful business plan among Latin American rebels of left and right Leo Grande and Sharpe [20] the combination of these methods and a religious, and not specifically political ideology, has begun a new trend [21]. These often have the character of the millenarian movements of the 19th and early 20th century, especially those of Melanesia de Waal, Malefijt [22], but their leadership and their weapons and methods are specifically a product of global technology and late modernity group organization, most notably in the recent transformation of a breakaway group from al-Qaeda in the form of ISIS/IS. They show parallels despite different religious clothing, as in the case of the Lord's Resistance Army in Uganda and its combination of an local history of the Acholi speakers and millenarian Christianity $[23,24]$. Suppression of indigenous religious movements in colonial possessions (e.g. Africa and Melanesia) has produced multiple local and regional rebellions [25].

Socialist and communist movements attempted to unite indigenous movements in a coherent ideology in the 20th century, but were largely co-opted by the nationalism of the First and Second World Wars. No ideological or political movement has succeeded in producing constructive means of intervention on behalf of local communities and indigenous peoples. Individual nations have been able to block international agencies' efforts as have multinational corporations in canceling legal redress [26,27]. Where law and diplomacy have failed what are the alternatives? One could imagine a new movement like the Khmer Rouge only projected internationally where the main ideological idea is the protection of indigenous culture and local control couched in a political analysis where wealth inequality and identified transnational ruling elite are pictured as the enemy. This is not far from the world view of Boko Haram. A similar rejection of western education and culture appeared in what Caldarola [28], called the "Modernist" period of Islamic history especially in the writings of al-Afghani and Muhammad Abdul. But there is nothing new about this situation and reminds one immediately of the situation in the first century of our common era when millions of Jews had fled the religious intolerance, political chaos and tribal conflict that led to the Roman occupation and later the two "insurgent" wars against fanatic nationalists [29]. What is significant is the failure of the west to 
consider the causes of the current rising successes of insurgents to recruit and expand their operations. The fact that al-Qaeda's North African branch appears to be engaged in transporting drugs as reported by Devlin Barrett (Associated Press, 19 December 2009) is only a natural evolution of the blindness that afflicts Western governments. In America the war on drugs has turned most of South and Central America into a battlefield and allied with the operations of authorities under the Patriot Act erodes American civil liberties.

Anti-knowledge or science movements are not rare in the history of other sects of the Judeo-Christian tradition as the history of the Inquisition demonstrates, or the acts during the Thirty Years War and other periods during the protestant reformation, or the anti-catholic violence and destruction of the monasteries during the English Revolution. Parallels can also be seen in America in the violence of the first and second great awakening or the purging of teachers and scientists in the 1950s during the red scare and house Un-American Activities Committee. Murder and violence have characterized the fanaticism of the anti-abortion movement with the killing or doctors, bombing of clinics and homes of Planned Parenthood workers and supporters across the country, especially in the 1980s and 1990s $[30,31]$.

Together counter insurgency operations and drug eradication and interdiction assaults have turned the world into an open American attack plan. The fallout from these operations, not only in loss of lives but income and the chaos and corruption that has followed, is creating the new armies America and the west face every day in new fields of resistance. Most of the casualties have been in tribal areas or where tribal populations have been pressed into urban masses. The conditions of life in these areas only fuels rebellion more. As Louis Dupree (1974) noted in his work on Afghanistan in the 1970s, it has been the fantasies of the west over drugs and tribes that have lead to the most serious disasters and mistakes in foreign policy in the past 200 years. The Italian example in Libya is an instructive one EvansPritchard [32], and informs us of the pattern in other locations as in the Belgian Congo or in the Americas in the extermination and pacification of Native Peoples during colonialism [33,34].

19th century Europe and its colonial spin-offs saw tribalism as its main enemy. To eliminate local power structures-kinship relationswould result in acculturation and order. This has largely been the strategy and rationale for globalism and staying in both Iraq and Afghanistan. Eliminate tribalism and you get docile workers, more profit and an end to resistance and terror. Instead, the 21st century is reaping a harvest of uprisings driven and magnified by the very acculturation that was expected to be so positive (profitable ?). Drugs and money play a significant role in the acceleration of that process. The intensity of the rebellion has created a determined and well organized model seen in Syria especially in the destruction of major urban centers as in Aleppo and Damascus which presages future urban warfare in other locations as in Nigeria's Kano. The nature of this resistance can be found in the failure of national governments as in Nigeria to respond proactively to local crisis, especially in the northeastern provinces and to the disruptions in local economic and political life by global investment. The assassination of the leader of Boko Haram and many of his early followers is a powerful motivation here and can go far to explain current conditions [35].

As Sociologist Max Weber [36] noted in the middle of the 19th century, peasants removed from their lands become docile and easily adapted to new forms of work, and Kevin Starr [37] found in his study concerning the early 20th century, that the invention of mass media made the manipulation of masses of rootless people an effective substitute for police and military action. Canetti [38] found that mass media conditioned people to act as crowd elements and has promoted a consciousness of crowd in modern society. The lack of reason and response to fact we are seeing in American political debate is evidence of how far this has developed. From crowd consciousness to mob action is only a small step. Murdock with his Fox News and Murphy of Liberty News instill this way of thinking every day, this "invasion of corporate news" as Andrew Edgecliffe-Johnson [39] has termed it has taken shape largely in the last two decades. However, media has come to be the voice of not just nations, but religions and ideologies. The cross-purposes and new techniques seem to be capable of motivating people to mass murder as in Rwanda and the states of the former Yugoslavia. However, all that is missing is a means to organize this resistance and for al Qaeda-like or Boko Haram-like organizations to see the opportunity and to fabricate an ideology that can be translated across cultural and religious barriers. ISIL (or IS) has produced a sophisticated media presence on the internet and in publications as in its financial report [40]. The outcome of such an ideology might be a collapse of social complexity in urban wars, where fanaticism and millenarianism like that of the Christian right blend with visions of a nuclear apocalypse. Using religion and ideology as a weapon is not new and currently the US is engaged in such a program that may backfire. Major General Douglas Stone told reporter Andrew Woods [41] of plans developed by the U.S. Army to utilize prisoners in the various camps held by the military for a grand reorganization of Islam into a more peaceful religion. Possessing a doctorate in public administration, and a degree from Stanford Business School and having made a fortune in Silicon Valley, General Stone outlined how the military would win the "battlefield of the mind." Under his direction, military prisons like Abu Ghraib were transformed after 2006 into seeing their detainees as strategic assets that could be reshaped to spread the seeds of a new Islam to the Middle East and Asia. Aided by the Rand Corporation, Stone and the USA military have undertaken a reeducation process and successfully released their charges (prisoners/students) back to their home countries. Of the 8,000 men released since 2006 only 24 have been recaptured, what Stone considers to be proof of success, interpreting this as a recidivism rate of less than $1 \%$. While this idea of Stone's and the program he describes may be simply a USA military disinformation project specially designed to discredit those returning or to increase suspicions among anti-USA groups in the Middle East, the concept is of interest as it reflects the first time in history that one military has used a religious sect as a counterintelligence movement. The issue of ethics aside, the idea of using religion as a weapon wielded by an enemy is dangerous, though during the Counter Reformation there were some efforts that came close to the effect if not the intent they were hardly successful. There is a liability to the leaders of al Qaeda, ISIS or a Boko Haram. By diluting their messages to encompass such a wider ideological perspective they may lose their core population support. Like the earlier effort of the Soviet Comintern, control of locally appropriated issues and movements is difficult and can have considerable unintended consequences.

\section{Disintegration of Empires: USSR and Ottoman Equals Chaos}

While it is clear that the collapse of the Ottoman Empire has created continuing violence and unrest over the past 100 years, the dismembering of the USSR is proving to be just as destabilizing. This is true not just in the various uprisings against Russian dominance as in 
Chechnya but the lingering tensions in former Soviet Republics like Ukraine. While religion and a lack of a history of self-government are factors so too is the history of repression of ethnicity and language. The second outcome is the desire of Russian politicians and a segment of the population to recreate the Soviet Empire as is seen today in Ukraine. This leads to international tensions as the west, which has won the cold war and imposed and overseen the disintegration of the USSR, attempts to extend its control as with its institutions like the European Union and NATO. One can say that just as the Ottoman collapse disintegrated the moral and political traditions of peaceful interaction of minorities based on the millet system Guclu [42], leading to the past 100 years of minority violence that has led to massacres and then totalitarian post-colonial regimes, the Soviet collapse has produced a similar vacuum of authority and cooperation leading to ethnic violence from Ukraine to Chechnya.

The most important fact of the current world order is the problem of the nations of the former USSR and the stability of Russia. Russia lacks an internal logic or ideology as both the Russian Empire and the USSR were expansionist in nature. A variety of tensions create an opportunist national government led by oligarchs often derived from the security apparatus of the USSR, but religion and kinship are in resurgent form in Russia as in the former Soviet Republics Gee, Metzo $[43,44]$. We have to keep in mind that the USSR was defeated and dismembered but unlike the experience of the Turks with the defeat of the Ottoman Empire, dismemberment was experienced at a time of invasion of the victorious allies of World War I. That invasion was defeated by Turkish forces led by Kemal Ataturk. The ability of the young Turks to revitalize Turkey and defeat the invasion is essential to understanding contemporary Turkey. It also informs us of Russia today, as Russia has had no unifying figure like Ataturk nor a coherent ideology to replace communism. It has, rather in some assessments become a Kleptocracy like some Third World states that are failed post-colonial entities, not even nations $[45,46]$.

As is Russia appears as a modern industrialized nation with a formidable military but a shattered civic life and poorly functioning institutions. At the same time Turkey seems to be descending into a process to reverse the westernization that Ataturk fashioned with a President who has created a powerful foundation from which to rule the nation and mimic the former Ottomans. While the Soviet Union disintegrated into a number of unstable states on the periphery of Russia with violent eruptions punctuating the transition from communism, Turkey exists surrounded by the chaos and repression that the disintegration of the Ottoman Empire has created and been sustained by the occupation, both military and economic, of western forces.

\section{Modernity and Rebellion}

We are seeing a combination of effects, drugs, religion, ideology and mass media all promoting anti-government action and directed toward specific "enemies." The drug war and expanding resource exploitation are motivating factors in rebellion worldwide what efforts might defuse the avalanche of conflict? Terry McDermott [47] and Jean Hatzfeld [48] have documented the process by which ordinary people become terrorists in an environment of economic and political transformation. The US invasions of Iraq with the continued occupation of military bases in the Saudi peninsula along with the invasion of Afghanistan and ongoing Israeli-Palestinian conflict have created an aroma of crisis.
Middle Eastern conflict however has been simmering since World War I due to the conditions of division Solh and Seale [49], with betrayal and assassinations molding the many kingdoms carved out of the Ottoman body [50]. The context for the defeat of the Soviets in Afghanistan was a clear road to future instability and chaos across the region which was obvious from history at the beginning [51,52]. If fact, western involvement in Afghanistan, Iran, Pakistan and Iraq has been so disastrous that the history reads as folly [53-55]. Russian campaigns to attempt to stabilize their southern tier have been brutal and expensive Rashid [54] ,but presage future problems as immigration spreads the fallout across the country and the globe as John Mackinlay [56], has predicted from all the Middle Eastern adventures of the west. Even countries like Algeria have purchased relative quiet at a tremendous price in blood Evans and Sessions [57,58] and it is a quiet that reeks of a hidden thunder as Josephus described for the Roman suppression of Palestine 2,000 years ago (Figure 2).

\section{Beheadings versus Drones}

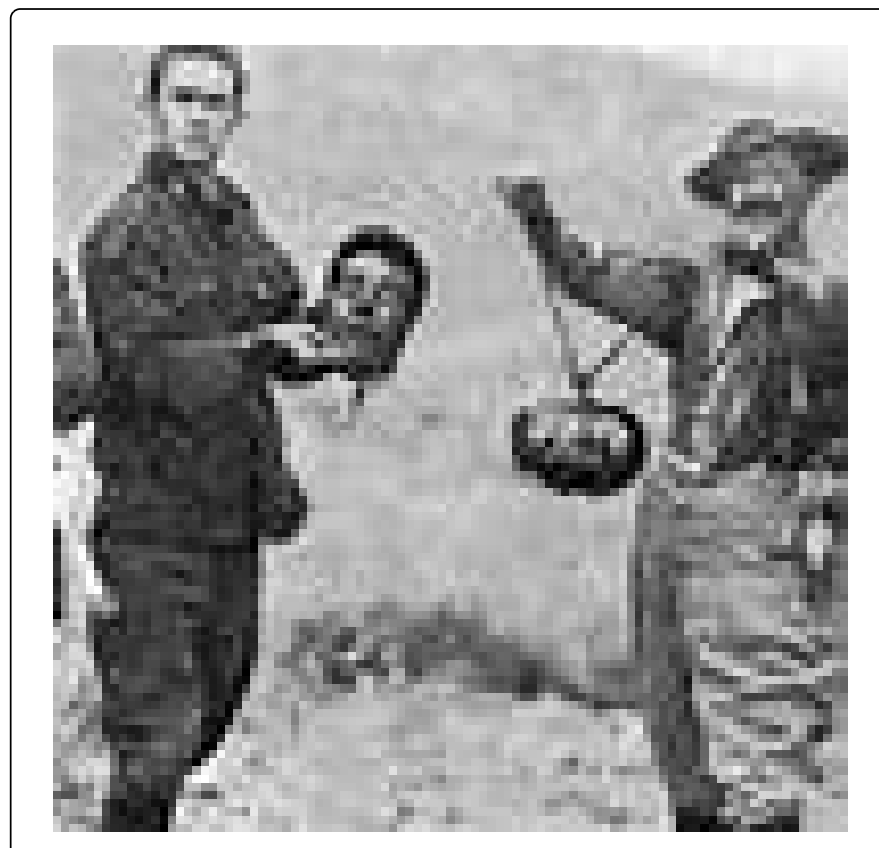

Figure 2: Belgian congo violence against natives.

Every period of history seems to have its characteristic form of terror, for the ancient world it was crucifixion, for the medieval, burning at the stake or drawing and quartering, for America hanging, or tar and feathering in different times and regions, in the modern period, gas chambers, throwing people from helicopters or napalming children and most recently, extraordinary renditions [59]. The image sends a message intended to control the viewer who receives it. As the Bureau of Investigative Journalism reported in January Serie [60] the number of drone killings under the Obama administration was over 2,400, mostly targeted political leaders or active members of organizations the administration considers terrorist. This does not include other drone killings controlled by nations sharing the technology like Israel that attack often the same organizations. While beheading was a frequent means of dispatching rebels in England, as in the famous beheading of Wat Tyler or Mary Queen of Scots, a beheading with a sword differs little from the use of a device like a 
guillotine except the latter is more effective and usually produces a uniform and effective end. Beheading was often practiced by colonial powers for slave rebellion [61]. Debating the issue of how humane such methods of execution are is only symbolic of relative power [62,63]. Other beheadings by organizations who used the media as a vehicle to promote terror include some of the Mexican drug [64]. Mutilations were common under colonial regimes by the colonial powers and were often arbitrary (Figure 3 is an example from Belgian Congo, see Hochschild [65], ISIS' use of similar methods should be seen in the context of response to colonial violence. One cannot terrorize populations for 400 years and then believe that in a few post-colonial decades all will be well. A related topic is the "black bag" or secret operation units of the US armed forces. Some of these units have been engaged in executions on a scale unknown before and the number of civilian deaths is unknown [66]. There is currently a media blitz spreading misinformation regarding the power and presence of alQaeda in various Middle Eastern and African countries including Libya and Mali. The Mali situation was consonant with my discussion above. The indigenous Tuareg have faced a variety of challenges from the central government and from competition for resources between a number of adjacent nations including Libya (under Gaddafi) and Chad. The Tuareg have responded with demands via a variety of civil means and with rebellions, the most recent was quite successful though it was overtaken by the more organized al-Qaeda affiliates. Due to the inability of nation states in the area to mount effective border controls the area is infested with illegal trade of every kind.

Thousands of indigenous problems fester across the globe like the Tuareg story, and yet it is the nature of the west's view of the world that allows it to ignore the fundamental economic problems of people and promote repression $[67,68]$.

Mutilations were common under colonial regimes by the colonial powers and were often arbitrary. Figure 3 is an example from Belgian Congo, Hochschild [65], ISIS' use of similar methods should be seen in the context of response to colonial violence. One cannot terrorize populations for 400 years and then believe that in a few post-colonial decades all will be well (Figure 3).

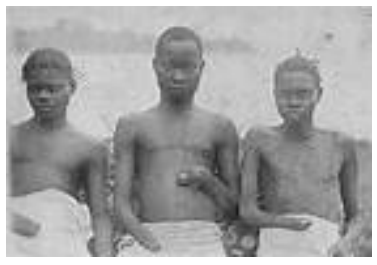

Figure 3: Mutilations under colonial regimes.

\section{ISIS and Rapid Conquest}

There has been much emphasis in the press over the rapid expansion of the ISIS (it has also called itself ISIL or Islamic State) in the past year. A variety of explanations have surfaced, but one that is consistent with the history of the area refers to the numerous times a mobile force has caused the collapse of empires and states. Braudel [69], noted that the Macedonian cavalry in Alexander the Great's army was more of a factor in the defeat of Darius' forces than the phalanx and cites later conquests of the early Muslim, Mongol and Turks as being dependent on a use of cavalry without respect to typical fighting tactics.
What appears on the horizon of terror is a relationship between state terror and local responses. Whether western military and intelligence created al-Qaeda to fight the Soviets the effect has been the same. We are told that documents seized in Iraq prove that the greatest number of "jihadis" not al-Qaeda (but that does not matter to most commentators) came from Libya ("Sinjar documents": http:// tarpley.net/docs/CTCForeignFighter.19.Dec07.pdf which were supposedly from al-Qaeda or "linked" groups and first published by the combating terrorism center (CTC) at West point. What is the authenticity of these documents? They had the function, like the "proofs" for Saddam's weapons of mass destruction, to build support for the war at home. From the beginning the sources used to identify the existence and history of al-Qaeda are the same used to give background to the development of the mujahideen in Afghanistan, Bill Moyers's sources are an example: (http://www.pbs.org/moyers/journal/ 07272007/alqaeda.html). Most are written by journalists like that by Abdel Bari Atwan (The Secret History of al-Qaeda) who has had a long career employed by Saudi family entities. Others by people like Bruce Hoffman (http://explore.georgetown.edu/people/brh6/) someone whose background is steeped in both the profits of a war contractor (RAND) and in the history of the Middle East struggle of Israel against her neighbors. Like many following this line of reasoning, he argues, "'It amazes me that people don't think there is a clear adversary out there, and that our adversary does not have a strategic approach." A worldwide conspiracy, of an invincible organization stalks a peaceful world. The image could be turned upside down with ease and we could view the entire anti-terrorist edifice as one great conspiracy to deprive the world of peace, freedom and prosperity. One of the glaring consequences of the post-9/11 world is the dramatic increase in wealth inequality and if we follow the money, the vast funneling of funds into security and military hardware since $9 / 11$ has benefitted a select sector of investors.

\section{Conclusion: A Ghost and the Tail Wagging the Dog}

As an anthropologist reading over this literature on al-Qaeda, I find it has certain interesting qualities. In other words, the al-Qaeda story has the mirror structure of many myths: for example, al-Qaeda is so well organized that it cannot be infiltrated and yet we know all about it because we have certain unnamed or elusive sources that can be counted on to produce detailed information about the organization. Usually such organizations are found in the popular press as conspiracy theories of one kind of Illuminati creation myth or another dating back to either the beginnings of civilization or the founding of America, but what is more disturbing is the fact that many individuals arrested or involved in terrorist acts or sect associated with al-Qaeda have been found to be government plants or recruited by government agents $[70,71]$, a more creative view is found in Robert Shea and Robert Wilson's books or their various followers). A paranoid personality is required to believe such tales and yet the entire world believes in the al-Qaeda creation myth. In these conspiracy myths everything can be explained by the secret organization. This is true of al-Qaeda. The defeat of the Soviets in Afghanistan, a number of terrorist attacks from the 1980s and 1990s and the substantial organization necessary for $9 / 11$ and then a host of others since of varying quality of execution and goal. No internal logic is necessary to unite the events or the actors. Goals and ends are secret knowledge and cannot be determined. .

The failure of al-Qaeda to take advantages of opportunities that are obvious that would further their power and build a movement is 
generally ignored. al-Qaeda has not linked with the international drug movement or illicit arms trade as underground leftist terrorists are supposed to have done in the 1970s, 80s and 1990s. One could assume this is due to their superior analysis that such involvements were detrimental to the movements that did, but this is open to interpretation. The same lack of action is true in regards to incidents of terror against the poor and disenfranchised in places like Central and South Africa, India and Central and South America, or any presence in labor struggles in the Middle East. Their supposed presence in Iraq and Afghanistan has been their central image, but in these areas their ability to produce any substantial base or victories is curious. Again, alQaeda seems more like a myth; a brutal Robin Hood who seldom wins anything but is always present to take the blame for everything. And now with ISIS there could not be a more perfect bogeyman. It is obvious that al-Qaeda and it affiliates in the Yemen and Somalia as well as Malia have been able to take advantage of failed states to intensify the degradation of civil life and the potential for the redevelopment of order and productivity. Unlike organizations like the Muslim Brotherhood, al-Qaeda has not shown any ability to create sustained local organizations for charities or business to aid local populations.

Now ISIS has taken this road though it is generally aimed at the Sunni/Shia separation and even more so a focus on a Unitarian line against all variations in belief. Some theorists have argued that this is a central theological rift, a break with bin Laden's "far enemy" (western powers) strategy (Ackerman, Malik and Khalili, 2015) or even his supposed "hearts and minds" tactics (Dyer, 2015) to a new focus on an ideological cleansing to produce religious purity. So ISIS' local focus is unlikely to produce an expansion beyond the Middle East to other conflicts with global capitalism. It appears increasingly as a Madhist type movement with limits to expansion and recruitment but an essential nativistic movement (Linton, 1943) built within the intolerant frame of the Judeo-Christian tradition characteristic of triumphal forms both of ancient Judiaism and colonial Christianity (Toynbee, 1958).

al-Qaeda/ISIL and bin Laden are the reason for the loss of freedoms in several western countries, most notably represented in the American Patriot Act and yet his pursuit (now the pursuit of ISIS as bin Ladin is dead) is the definition of the struggle to regain it. A more coincident construction to Eric Blair's book, 1984 would be hard to fabricate. Like a religion, belief in the existence of al-Qaeda cannot be proven or disproven and skeptics are worse than heretics or the old unbelievers of international communism being behind every protest or uprising of the 1950s. Such attitudes define "fellow travelers" in the anticommunist vernacular of "unpatriotic co-conspirators." Yet if we use logic to address the ideology of the "al-Qaeda conspiracy" we might find that the very policies that have been invented to fight terror have created more from Saddam to bin Laden to ISIS there seems to be no end in this dance. Is there a way out of this straight-jacket the world finds itself in?

Demands of the USA and western forces in general to defeat or destroy ISIS are just as naïve or based in conflict of interest as those which led to the invasion of Iraq in 1990, 2003 and Afghanistan in 2001. Eradication of ISIS, Boko Haram, the Naxalites and others yet to come, is not possible using force. What will eventually happen will be more urban wars which major modern cities like Damascus and Aleppo will suffer months if not years of armed struggle and repression by western forces. Such an enterprise would be like the attempted effort to have Ottomans influence the Wars of the Reformation, had they aided with or attacked the early Protestants. They did neither for in 1525 the French were destroyed at Pavia and their king, Francis was taken prisoner. Martin Luther declared to Charles V's face the fanaticism that was to rend Europe in a great war. But a rising fanaticism in the Ottoman east caused Selim the Grim to be occupied suppressing Shite rebellions until 1520 when his son, Suleiman the Lawgiver (Magnificent in most European histories), came to the throne.

Selim the Grim had consolidated the world of Islam, from Persia to Spain and became the Caliph and Commander of the Faithful. Islam was at its political and cultural height. Just as Suleiman crushed the Knights of St. John on Rhodes and began his assault on Hungary he received a letter from the imprisoned King Louis in Spain asking his help, which he rejected. In 1526 Suleiman exterminated the Hungarian army at Mohacs and stormed Buda. In 1529 Suleiman advanced against Vienna with 200,000 troops, but while the Christian kingdoms were divided (and the Pope abandoned the defense to concentrate on suppressing Florence) they set aside difference enough to produce an effective, yet desperate defense of Vienna [72].

Suleiman failed and yet the worst of the Wars of the Reformation were yet to come. Europe was left to fight it to the end. The nations of Islam cannot do this with the interference of the west, yet such a consolidation would likely continue the recent Arab Spring and sweep away not only the western-leaning Arab kingdoms, but also the colonial boundaries producing a new configuration for the people of the Middle East. Whether the west can continue to constrain these peoples and prevent such a transformation is as unlikely as Suleiman's attempt to conquer Europe. It often seems as if western policies are built on the model of the Mahdist transformation Barclay [28], where a triumphant and revolutionary messianism that had defeated the British army in Sudan to establish an indigenous regime was eventually compromised by colonial intrigue into a collaboration partner. That process was initiated by a failure of the Mahdist movement to expand, especially to Ethiopia where the Christian Emperor, Yohannes IV, offered an anti-European alliance that was rejected by the Mahdist leaders. Instead, their ideology constructed around Islam, led them to invade Ethiopia and waste both nations' energies and resources. The British reinvasion was successful but given the international situation required some interaction with former Mahdist followers [73].

The idea of some accommodation, the "preservation of foreign investments" is an attempt to retain aspects of colonial control and perpetuate client allies and institutions against complete "reindigenation." Here the example from the uprising in the Yucatan is relevant. The Maya fought in groups as reported 400 years before during the Conquest, yet even in the historical context of the European revolutions of 1848 that gave shape to democratic movements in Central and South America, the Mayan leaders could not create alliances with a broader movement for self-determination, mainly due to the racism that dominated European society [74,75].The danger of this (successful indigenous uprisings) was less during the period of Soviet competition as communism is a form of western progressivism as Jomo Kenyatta realized Berman[76], situated in state power and authority over minorities.

Like the Methodists, ISIS's ideology prevents it from constructing wider alliances and limits its ability to integrate a global critique to achieve an anti-colonial expansion. The parallel with the Khmer Rouge also is of interest where an extreme anti-western interpretation of Marxism led to a failed attempt at de-colonialization of the population. 
For students of civilization, the problems caused by the collapse of the Ottoman and Soviet empires will be a focus of attention for years to come, yet they provide a fruitful source of analysis to the study of social complexity and its fragility. Yet as Moyo [77] has noted, development and foreign aid is driving change and chaos across the developing world along with the conflict that missionary work brings. Missionaries are often seen a agents of foreign colonialism [78,79], and their behavior in criticizing local indigenous religions or other major world religions (especially Islam) feeds local tensions as money and personnel for missionary work comes from abroad and has always represented colonial issues vs local initiative and ideology. What seems clear is that unless some international entity can be created that can control international finance and limit the rights of international corporations, then the lack of local justice will continue to produce terror across the globe.

The behavior of some of the current rebel groups, for example, ISIS shows definite lapses in organization and knowledge of how to implement state formation operations. Soloman [80] describes some of these deficiencies, yet this is not significantly different from local operations that evolved from drug organizations in places like Columbia in the 1990s, parallels in sophistication of economic control and organization can be gleaned from other examples in history, like the crime lords of Chicago in the 1920s [81]. With the world awash in former military highly trained operatives the potential for improving personnel quality and operation efficiency is quite good. With ISIS already franchising operations in some of its periphery the pattern is already well established. Governments might consider suppressing or tightly regulating the operations of private security services as they are increasingly being used as virtual armies across the globe by both legitimate businesses editorial [82], and governments as well as those in gray areas of legality, as in the Poroshenko/Kolomoisky affair in Ukraine Olearchyk [83] and outright mercenary operations for profit [84]. Some of these have evolved from military downsizing in the west and the extensive use of contract services since the 1980s in the USA.

Loyalties of such organizations are certainly questionable as are their chain of command and responsibility. As certainty of messaging and financial information become more vulnerable to hacking, issues of control by governments will become more unstable and involvement of citizens distant. Access to ownership documentation in identity theft has risen in sophistication as well and threatens to breach the bastions of banking as more value is shifted to dark money and shadow financial entities. This complex scenario of the future where war and non-war violence and electronic sabotage of varied loyalties and semilegal entities has been sketched by [85].

\section{References}

1. Balagopal K (1987) A Tale of Arson. Economic and Political Weekly 22: 1169-1171.

2. Gupta TD (2006) Maoism in India: Ideology, Programme and Armed Struggle, Economic and Political Weekly 41: 3172-3176.

3. Anonymous (2014) India- 'Foil Vedanta' protests erupt in Delhi, The Ecologist, India.

4. Letourneau A (2014) Illegal Mining Severely Impacting Peruvian Environment, Forbes.

5. Al-Yassini AS (1982) Saudi Arabia: the kingdom of Islam, Religions and Societies: Asia and the Middle East, Mouton Press, Berlin, Germany 61-84.

6. Wilson R, Freeth Z (1983) The Arab of the Desert, London, UK.

7. Doran MS (2004) The Saudi Paradox, Foreign Affairs 83: 35-51.
8. Hamidi A (2009) Inscriptions of violence in Northern Yemen: haunting histories, unstable moral spaces, Middle Eastern Studies 45: 165-187.

9. King JR (2012) Zaydi revival in a hostile republic: competing identities, loyalties and visions of state in Republican Yemen, Arabica 59: 404-445.

10. Hegghammer T (2008) Islamist violence and regime stability in Saudi Arabia, International Affairs 84: 701-715.

11. Bodley JH (1988) Tribal Peoples and Development Issues, Mountain View, Mayfield Publishing, California, USA.

12. Jack G (1987) The Interface Between the Written and the Oral, Cambridge, Cambridge University Press, USA.

13. Daragahi B, Solomon E (2014) Fuelling Isis Inc. The Financial Times, USA.

14. Bagley B (1988) Colombia and the war on drugs, Foreign Affairs Fall 67: 70-92.

15. Pardo R (2000) Colombia's two-front war, Foreign Affairs 79: 64-73.

16. United States Department of the Treasury (2004)Treasury designates financial web of Columbian drug lords," Press Center, Office of Public Affairs.

17. Salehyan I (2010) The delegation of war to rebel organizations, The Journal of Conflict Resolution 54: 493-515.

18. Sassen S (2012) Cities in a World Economy, Sage Publication, (4thedn), Los Angeles, USA.

19. Neuwirth R (2006) Shadow Cities: A Billion Squatters, a New Urban World, Routledge, New York, USA.

20. Leo G, William S, Kenneth E (2000) Two Wars or One? Drugs, Guerrillas, and Colombia's New Violencia, World Policy Journal 17: 1-11.

21. Ellis S, Ter H (2004) Worlds of Power, Religious Thought and Political Practice in Africa, Oxford University Press, New York, USA.

22. De Waal M (1968) Religion and Culture: An Introduction to the Anthropology of Religion, MacMillan, USA.

23. Van Acker F (2004) Uganda and The Lord's Resistance Army: The New Order No One Ordered. African Affairs 103: 412.

24. Nhema AG (2008) The Resolution of African Conflicts: the Management of Conflict Resolution \& Post-conflict Reconstruction, Ohio University Press, USA.

25. Morris B (2006) Religion and Anthropology: A Critical Introduction, Cambridge, University of Cambridge Press, USA.

26. Gupta A (2005) Human Rights of Indigenous Peoples, Isha Books, Delhi, India.

27. Human Rights Watch (2001) Violence and Political Impasse in Papua 25: 10 .

28. Barclay HB (1982) Sudan: On the frontier of Islam, Religions and Societies: Asia and the Middle East, Mouton Publishers, Berlin, Germany 147-171.

29. Flavius JT (1959) The Jewish War, London, Penguin Classics, written in 75 A.D, Penguin edition, UK.

30. Hoffman M, Flanders L, Rosen R (2001) Welcome to My World, Womens' Review of Books. 8-9.

31. Terri S, Patricia D (1985) State laws and the provision of family planning and abortion services in 1985 Family Planning Perspectives 6: 262-266.

32. Evans-Pritchard EE (1954) The Sanusi of Cyrenica, Oxford: The Clarendon Press, UK.

33. Todorov T (1984) The Conquest of America, Harper Perennial, New York, USA.

34. Hemming J, Red G (1978) The Conquest of the Brazilian Indians, Cambridge, Harvard University Press, USA. 1500-1760.

35. Adesoji A (2010) The Boko Haram uprising and Islamic revitalism in Nigeria, Africa Spectrum 45: 295-108.

36. Weber M (1958) The Protestant Ethic and The Spirit of Capitalism, The Scribner Library, Translated by Talcott Parsons, Scribner \& Sons, Newyork, USA.

37. Starr K (1985) Inventing the Dream, Oxford, Oxford University Press, USA.

38. Cannetti E (1962) Crowds and Power, Viking Press, New York, USA. 
Page 8 of 8

39. Edgecliffe-Johnson A (2014) The invasion of corporate news, The Financial Times, UK.

40. Khalaf R, Jones S (2014) Selling terror: how ISIS details its brutality, Financial Times, UK.

41. Woods A (2008) The Business End, Part I and Part II, The Financial Times, UK.

42. Guclu Y (2010) Armenians and the Allies in Cilicia: 1914-1923, Utah Series in Turkish and Islamic Studies, Salt Lake City, University of Utah Press, USA.

43. Knudson GG (1995) Geography, nationality and religion in Ukraine: a research note, Journal for the Study of Religion 3: 383-390.

44. Metzo KR (2006) Exchange in Buriatia: Mutual Support, Indebtedness, and Kinship, Ethnology 4: 287-303.

45. Gloster-Coates P, Quest L (2005) Kleptocracy: curse of development International Social Science Review 80: 3-19.

46. Shleifer A, Treisman D (2005) A normal country: Russia after Communism, The Journal of Economic Perspectives 19: 151-174.

47. McDermott T (2005) Perfect Soldiers, Harper Collins, New York, USA.

48. Hatzfeld J (2005) Machete Season: The Killers in Rwanda Speak, Farrar Straus Giroux.

49. Seale P (2010) The Struggle for Arab Independence, Cambridge, Cambridge University Press, USA

50. Allawi A (2014) Faisal I of Iraq New Haven, Yale University Press, USA.

51. Braithwaite $\mathrm{R}$ (2009) The familiar road to failure in Afghanistan, Financial Times, UK.

52. George C (2003) Charlie Wilson's War, Atlantic Monthly, New York, USA.

53. Dalrymple W (2013) Return of a King: The Battle for Afghanistan, New York, Bloomsbury, USA.

54. Rashid A (2002) Jihad: The Rise of Militant Islam in Central Asia, Penguin Books, New York, USA.

55. Chandrasekaran R (2012) Little America: The War within the War for Afghanistan, New York, and Bloomsbury, USA.

56. Mackinlay J (2009) The Insurgent Archipelago, Columbia/ Hurst, New York, USA.

57. Evans M (2011) Algeria: France's Undeclared War, Oxford, Oxford University Press, USA.

58. Jennifer SE (2011) By Sword and Plow: France and the Conquest of Algeria, Cornell, Cornell University Press, USA.

59. Alan WC (2012) Rendition to Torture, New Brunswick, Rutgers University Press, USA.

60. Serie J (2014) Drone Warfare: More than 2,400 dead as Obama 's drone campaign marks five years, Bureau of Investigative Journalism, London, UK.

61. Grandin G (2014) The Empire of Necessity: The Untold Story of a Slave Rebellion in the Age of Liberty, One world, Metropolitan Press, New York, USA.

62. Anyanwu, Ogechi E (2005) Crime and Justice in Postcolonial Nigeria: The Justifications and Challenges of Islamic Law of Shari'ah Journal of Law and Religion 21:2: 315-347.
63. Michel F (1977) Discipline and Punish, Vintage Books, New York,USA.

64. Raisa B (2012) Cartel rivals behead Zetas on camera, ABC News, USA.

65. Hochschild A (1988) King Leopold's ghost: a story of greed, terror, and heroism in Colonial Africa / Adam Hochschild. Houghton Mifflin, Boston, USA.

66. Mazzetti M, Kulish N, Drew C, Kovaleski SF, Naylor SD, et al. (2014) An elite Navy unit's blurred lines, International New York Times, USA.

67. Thomas K, Lee H (2006) Without Precedent: The Inside Story of the 9/11Commission, Alfred A. Knopf, New York, USA

68. Lawrence W (2006) The Looming Tower: Al-Qaeda and the Road to 9/11, New York, USA.

69. Fernand B (2001) Memory and the Mediterranean, edited by Rosellyne De Ayala and Paule Braudel, Trans. By Sian Reynolds, Vintage Books, Random House, New York, USA.

70. Sam S, Denny W (2014) Lodi terror suspect says he would not have acted against his own country, Sacramento Bee, USA.

71. Cahal M, Kim S (2013) Terror in Woolwich: MI5 'tried to recruit suspect in Kenyan jail, The Independent, USA.

72. Fletcher P (1956) The Battles That Changed History, Garden City, Dolphin Books, USA.

73. Abdel Salam S (2006) Sudan the Contemporary Middle East, Routledge, London, UK.

74. Nelson R (1964) Caste War of the Yucatan, Stanford, Stanford University Press, USA.

75. Priscilla R (1960) Revolutions of 1848, New York, Harper Torch books, first published by Princeton University Press, USA.

76. Bruce B (1996) Ethnography as politics, politics as ethnography: Kenyatta, Malinowski, and the making of Facing Mount Kenya, CJAS 30: 313-344.

77. Moyo D (2009) Dead Aid, New York, USA

78. Robert F (2003) Christians and Missionaries in India: Cross-Cultural Communication since 1500, Cambridge, Eerdmans, USA.

79. Firoze M, Carl O (2002) The Missionary Position: NGOs and Development in Africa, International Affairs (Royal Institute of International Affairs 78: 567-583.

80. Erika S (2015) Meet the Boss, Financial Times, USA.

81. Ethan N (2007) Drugs, Foreign Affairs, No. 162. 24(26): 28-30.

82. Editorial (1992) Tea industry's private army, Economic and Political Weekly 27(42): 2273

83. Poroshenko OR (2015) warns rival over 'pocket army, Financial Times, USA.

84. David S (1998) Private Armies and Military Intervention, Oxford University Press, New York, USA.

85. Wittes B, Blum G (2015) The Future of Violence, Basic Civitas, USA. 